DOI:

UDC 656.135 .8

B. Sereda, Ph.D., Professor, seredabp@ukr.net

D. Mukovska, graduate student

D. Sereda, Ph.D., Senior lecturer

Dniprovsky State Technical University, Kamianske

\title{
RESEARCH OF THE WORK OF DUMP TRUCKS IN THE TRANSPORT AND TECHNOLOGICAL SYSTEM OF RECYCLING OF TECHNOLOGICAL WASTE OF METALLURGICAL MOTHERLAND
}

In the course of this research, statistical data on the operation of BelAZ heavy-duty dump trucks with a capacity of 30 and 42 tons in the transport and technological system of recycling of technological waste of two sections of the slag processing plant for 31 days were processed. Expertly identified 18 parameters that characterize the quality of dump trucks, namely - the number of riders $\left(z_{1}\right)$, the volume of cargo transported $\left(z_{2}\right)$, mileage $\left(z_{3}\right)$, the number of operating hours $\left(z_{4}\right)$, the actual fuel consumption $\left(z_{5}\right)$, technical speed $\left(z_{6}\right)$, travel time $\left(z_{7}\right)$, idling $\left(z_{8}\right)$, parking duration $\left(z_{9}\right)$, number of stops $\left(z_{10}\right)$, duration of stops $\left(z_{11}\right)$, number of stops $\left(z_{12}\right)$, operating speed $\left(z_{13}\right)$, static load capacity factor $\left(z_{14}\right)$, average ride duration $\left(z_{15}\right)$, average ride distance $\left(z_{16}\right)$, average ride length $\left(z_{17}\right)$, idle time under load (unloading) $\left(z_{18}\right)$. The practical implementation of the method is carried out on a computer in the module "Factor analysis" of the integrated system of statistical analysis STATISTICA. In the process of component analysis, the number of the most important main components was substantiated, the relationship between the main components and the initial parameters was established, and a meaningful interpretation of the main components was performed. idling.

Keywords: dump truck, ride, component analysis, metallurgical slag, operating speed, hours,

В процесі даного дослідження були опращьовані статистичні данні про роботу великовантажних самоскидів БелАЗ вантажопідйомністю 30 ma $42 \mathrm{~m}$ в транспортно-технологічній системи рециклінгу технологічних відходів двох ділянок ичеху илакопереробки протягом 31 доби. Експертним шляхом були виділені 18 параметрів, які характеризують якісну роботу самоскидів, а саме, - кількість їзок $\left(z_{1}\right)$, обсяг перевезеного вантажу $\left(z_{2}\right)$, пробіг $\left(z_{3}\right)$, кількість моточасів роботи $\left(z_{4}\right)$, фактична витрата палива $\left(z_{5}\right)$, технічна швидкість руху $\left(z_{6}\right)$, час у русі $\left(z_{7}\right)$, холостий хід $\left(z_{8}\right)$, тривалість стоянок $\left(z_{9}\right)$, кількість стоянок $\left(z_{10}\right)$, тривалість зупинок $\left(z_{11}\right)$, кількість зупинок $\left(z_{12}\right)$, експлуатаційна швидкість руху $\left(z_{13}\right)$, коефіцієнт статичного використання вантажопідйомності $\left(z_{14}\right)$, середня тривалість їздки $\left(z_{15}\right)$, середня відстань їздки $\left(z_{16}\right)$, середня довжсиа їздки $\left(z_{17}\right)$, час простою під завантаженням (розвантаженням) $\left(z_{18}\right)$. Практична реалізачія методу здійснена на ЕОМ у модулі «Факторний аналіз» інтегрованої системи статистичного аналізу STATISTICA. В процесі компонентного аналізу було обтрунтовано кількість найбільш вагових головних компонент, встановлено співвідношення між головними компонентами і вихідними параметрами, проведено змістовне інтерпретування головних компонент.

Ключові слова: самоскид, їздка, компонентний аналіз, металургійний шлак, експлуатаціийна швидкість, мотогодини, холостий хід.

Introduction and problem statement. Technical and operational indicators of dump trucks during transportation of technological waste of the main production of metallurgical enterprises are determined by a large number of features and have a close connection with the technology of main production, specialization of cargo points, technology of cargo points, etc. Therefore, for a complete technical and economic characteristics of the process of operation of dump trucks, it is necessary to have statistical information for a large number of different physical characteristics. If the process of dump trucks includes a large number of features, the meaningful characterization of the relationships 
identified by regression analysis becomes a non-trivial task. One of the methods of multidimensional statistical analysis, the principal components method, can be successfully used to study such processes. The principal components method is used to group the starting factors so that the members of the group are correlated with each other, but the group as a whole would be independent of other groups. Linearly independent groups of factors are called the main components $[1,2,3]$.

One of the important advantages of the principal components method is that it allows to represent the process of behavior of the studied object in the form of a set of independent (statistically) components, which allows to study the studied system using a reference model and conduct research by comparing the reference model with real system behavior. . Thus, the essence of the principal components method is to display complex processes in a simplified form and to study possible options for their development in a model situation [4].

The purpose of the work. On the basis of the statistical data characterizing work of dump trucks to carry out the analysis of parameters of work of dump trucks in processes of recycling of technological waste of the metallurgical enterprise by a method of the main components.

Results of work. In the course of this research, statistical data on the operation of BelAZ heavy-duty dump trucks with a capacity of 30 and 42 tons in the transport and technological system of recycling of technological waste of two sections of the slag processing plant for 31 days were processed.

Expertly identified 18 parameters that characterize the quality of dump trucks, namely - the number of riders $\left(\mathrm{z}_{1}\right)$, the volume of cargo transported $\left(\mathrm{z}_{2}\right)$, mileage $\left(\mathrm{z}_{3}\right)$, the number of operating hours $\left(\mathrm{z}_{4}\right)$, the actual fuel consumption $\left(\mathrm{z}_{5}\right)$, technical speed $\left(\mathrm{z}_{6}\right)$, travel time $\left(\mathrm{z}_{7}\right)$, idling $\left(\mathrm{z}_{8}\right)$, parking duration $\left(z_{9}\right)$, number of stops $\left(z_{10}\right)$, duration of stops $\left(z_{11}\right)$, number of stops $\left(z_{12}\right)$, operating speed $\left(z_{13}\right)$, static load capacity factor $\left(\mathrm{z}_{14}\right)$, average ride duration $\left(\mathrm{z}_{15}\right)$, average ride distance $\left(\mathrm{z}_{16}\right)$, average ride length $\left(\mathrm{z}_{17}\right)$, idle time under load (unloading) $\left(\mathrm{z}_{18}\right)$.

The practical implementation of the method is carried out on a computer in the module "Factor analysis" of the integrated system of statistical analysis STATISTICA [5].

Component analysis of the studied process of cargo processing is performed in the following sequence [6].

1. Justification of the number of the most important main components. For the accepted initial number of principal components $\mathrm{m}=18$, the eigenvalues of the principal components were calculated, which characterize the contribution of the corresponding component to the total variance (Tabl. 1).

To substantiate the number of main components, we use an approach in which the contribution $\mathrm{V}_{\mathrm{r}}$ of the next main component included in the consideration must satisfy the condition $\mathrm{v}_{\mathrm{r}} \geq 1$. $[7,8,9]$ According to this approach, it is advisable to use the first 4 main components for further research to carry out the next stages of component analysis, we select the first 4 main components.

Table 1. Contributions of principal components to the total variance

\begin{tabular}{|c|c|c|}
\hline \multirow{2}{*}{$\begin{array}{c}\text { The amount of component } \\
\text { contribution }\end{array}$} & \multicolumn{2}{|c|}{ Type of contribution } \\
\cline { 2 - 3 } & \multicolumn{2}{|c|}{ Absolute } \\
\hline $\mathrm{F}_{1}$ & 8,486 & Relative, \% \\
\hline $\mathrm{F}_{2}$ & 3,212 & 47,145 \\
\hline $\mathrm{F}_{3}$ & 1,805 & 17,842 \\
\hline $\mathrm{F}_{4}$ & 1,393 & 10,029 \\
\hline $\mathrm{F}_{5}$ & 0,936 & 7,741 \\
\hline $\mathrm{F}_{6}$ & 0,743 & 5,199 \\
\hline $\mathrm{F}_{7}$ & 0,498 & 4,129 \\
\hline $\mathrm{F}_{8}$ & 0,321 & 2,767 \\
\hline $\mathrm{F}_{9}$ & 0,284 & 1,782 \\
\hline $\mathrm{F}_{10}$ & 0,161 & 1,577 \\
\hline $\mathrm{F}_{11}$ & 0,066 & 0,894 \\
\hline & & 0,367 \\
\hline
\end{tabular}


Continue of the table 1.

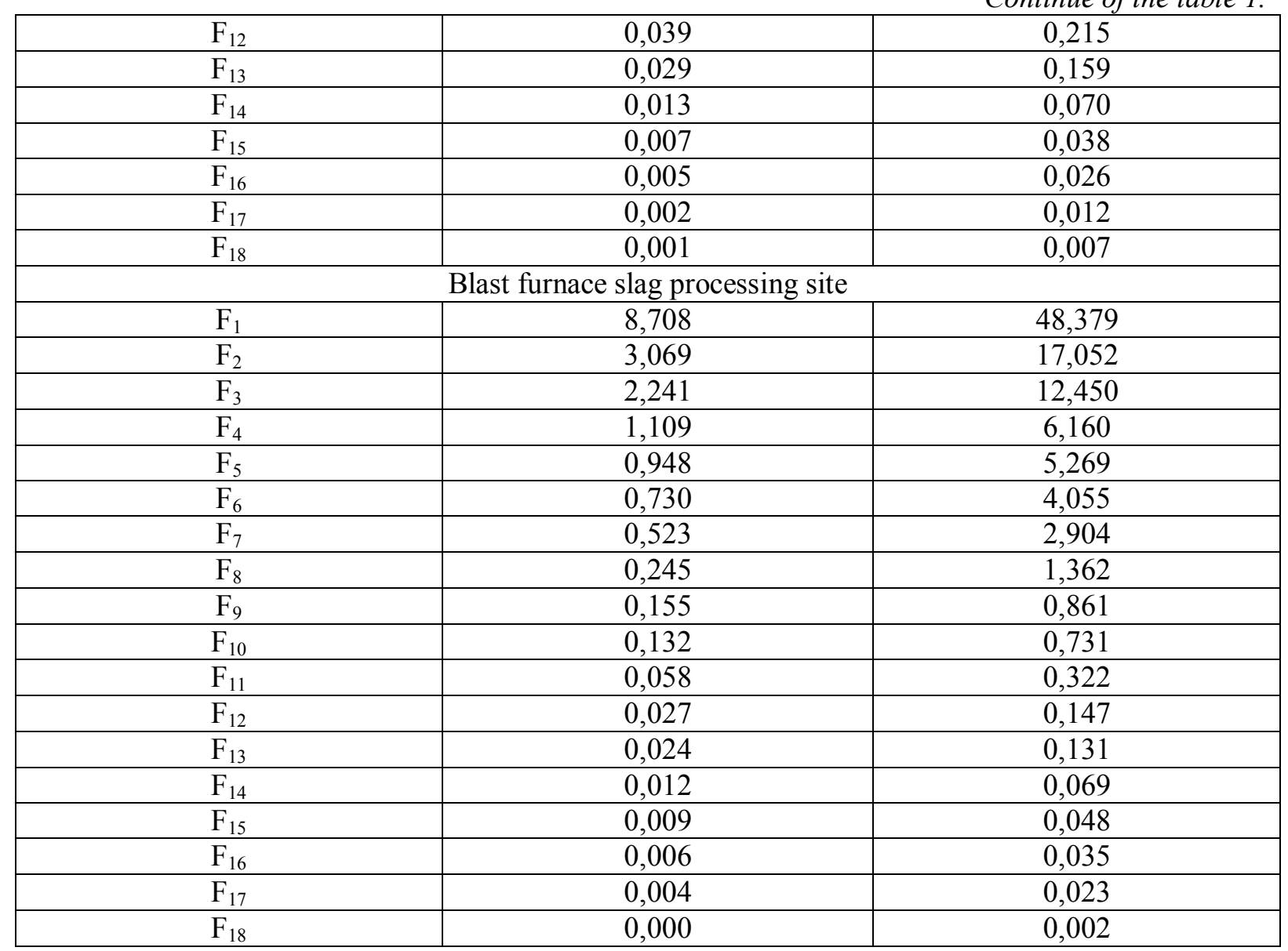

2. Establishing relationships between the main components and output parameters. Such relations are mathematical models of the studied process. To build models, a matrix of factor loads is used, obtained as a result of component analysis and reduced to 4 selected components (Tabl. 2).

Components with a value of factor load $\mathrm{f}<0.5$ in the model were not included.

Table 2. Factor load matrix

\begin{tabular}{|c|c|c|c|c|}
\hline \multirow{2}{*}{$\begin{array}{c}\text { Output parame- } \\
\text { ters }\end{array}$} & \multicolumn{4}{|c|}{ Values of weights } \\
\cline { 2 - 5 } & $\mathrm{a}_{1}$ & $\mathrm{a}_{2}$ & $\mathrm{a}_{3}$ & $\mathrm{a}_{4}$ \\
\hline \multicolumn{5}{|c|}{ Open-hearth slag processing site } \\
\hline $\mathrm{z}_{1}$ & $\mathbf{0 , 9 6 8}$ & $-0,082$ & $-0,014$ & $-0,153$ \\
\hline $\mathrm{z}_{2}$ & $\mathbf{0 , 9 2 8}$ & $-0,207$ & $-0,033$ & 0,093 \\
\hline $\mathrm{Z}_{3}$ & $\mathbf{0 , 8 5 3}$ & $-0,274$ & 0,093 & 0,287 \\
\hline $\mathrm{z}_{4}$ & $\mathbf{0 , 9 3 8}$ & 0,199 & $-0,113$ & 0,208 \\
\hline $\mathrm{z}_{5}$ & $\mathbf{0 , 8 5 1}$ & $-0,056$ & $-0,069$ & 0,265 \\
\hline $\mathrm{z}_{6}$ & $-0,066$ & $\mathbf{- 0 , 6 1 7}$ & $-0,475$ & 0,248 \\
\hline $\mathrm{z}_{7}$ & $\mathbf{0 , 8 0 4}$ & 0,158 & 0,360 & 0,074 \\
\hline $\mathrm{z}_{8}$ & $\mathbf{0 , 7 2 5}$ & 0,177 & $-0,297$ & 0,398 \\
\hline $\mathrm{z}_{9}$ & $\mathbf{0 , 6 6 6}$ & $-0,042$ & $\mathbf{0 , 5 2 6}$ & $-0,354$ \\
\hline $\mathrm{z}_{10}$ & $\mathbf{0 , 6 6 7}$ & $-0,050$ & $\mathbf{0 , 5 2 7}$ & $-0,354$ \\
\hline $\mathrm{z}_{11}$ & $\mathbf{0 , 6 6 5}$ & $\mathbf{0 , 5 9 3}$ & $-0,329$ & 0,053 \\
\hline $\mathrm{z}_{12}$ & $\mathbf{0 , 9 4 0}$ & $-0,076$ & $-0,199$ & $-0,013$ \\
\hline $\mathrm{z}_{13}$ & $-0,103$ & $\mathbf{- 0 , 8 5 2}$ & 0,359 & 0,231 \\
\hline
\end{tabular}




\begin{tabular}{|c|c|c|c|c|}
\hline \multicolumn{5}{|c|}{ Continue of the table 2. } \\
\hline$Z_{14}$ & $-0,487$ & $-0,279$ & 0,398 & 0,550 \\
\hline$Z_{15}$ & $-0,184$ & $\mathbf{0 , 8 9 7}$ & 0,053 & 0,068 \\
\hline$Z_{16}$ & $\mathbf{- 0 , 6 9 4}$ & $-0,129$ & $-0,255$ & $\mathbf{0 , 6 3 4}$ \\
\hline$Z_{17}$ & $-0,278$ & 0,316 & 0,482 & 0,176 \\
\hline$Z_{18}$ & $-0,348$ & $\mathbf{0 , 7 2 2}$ & 0,211 & 0,095 \\
\hline \multicolumn{7}{|c|}{ Blast furnace slag processing site } \\
\hline$Z_{1}$ & $\mathbf{0 , 9 4 1}$ & $-0,038$ & 0,194 & 0,227 \\
\hline$Z_{2}$ & $\mathbf{0 , 9 2 1}$ & $-0,020$ & 0,173 & $-0,069$ \\
\hline$Z_{3}$ & $\mathbf{0 , 9 5 3}$ & 0,122 & $-0,226$ & $-0,085$ \\
\hline$Z_{4}$ & $\mathbf{0 , 8 1 5}$ & $\mathbf{- 0 , 5 1 5}$ & 0,052 & 0,054 \\
\hline$Z_{5}$ & $\mathbf{0 , 9 3 2}$ & 0,045 & $-0,062$ & $-0,480$ \\
\hline$Z_{6}$ & 0,388 & $\mathbf{0 , 5 1 8}$ & $-0,396$ & 0,078 \\
\hline$Z_{7}$ & $\mathbf{0 , 9 5 9}$ & 0,014 & $-0,139$ & $-0,189$ \\
\hline$Z_{8}$ & 0,441 & $\mathbf{- 0 , 7 7 2}$ & 0,199 & 0,232 \\
\hline$Z_{9}$ & $\mathbf{0 , 8 9 6}$ & 0,019 & 0,051 & 0,117 \\
\hline$Z_{10}$ & $\mathbf{0 , 9 2 4}$ & 0,053 & $-0,050$ & $-0,247$ \\
\hline$Z_{11}$ & 0,388 & $\mathbf{- 0 , 8 3 4}$ & 0,103 & 0,065 \\
\hline$Z_{12}$ & $\mathbf{0 , 9 4 9}$ & 0,000 & $-0,014$ & 0,096 \\
\hline$Z_{13}$ & 0,486 & $\mathbf{0 , 7 7 2}$ & $-0,286$ & $\mathbf{0 , 7 0 7}$ \\
\hline$Z_{14}$ & $-0,275$ & $-0,203$ & $-0,218$ & 0,185 \\
\hline$Z_{15}$ & $-0,250$ & $\mathbf{- 0 , 5 1 4}$ & $-\mathbf{0 , 7 4 7}$ & 0,120 \\
\hline$Z_{16}$ & $-0,022$ & 0,347 & $-0,106$ & $-0,252$ \\
\hline
\end{tabular}

Note: The factor loads included in the model are marked in bold

Models of the relationship of the original features (parameters with the main componentsz $z_{i}=\varphi$ (a国) are constructed in accordance with formula (1) [10]

$$
\mathrm{z}_{\mathrm{j}}=\mathrm{a}_{\mathrm{j} 1} \mathrm{~F}_{1}+\mathrm{a}_{\mathrm{j} 2} \mathrm{~F}_{2}+\ldots+\mathrm{ajkFjk}+\ldots+\mathrm{a} \square \mathrm{nFn}(\mathrm{j}=1,2 \ldots \mathrm{n}),
$$

where $_{\mathrm{j}}$ - is the normalized value of the feature obtained from the model; $a_{\mathrm{j} 1}, a_{\mathrm{j} 2} \ldots a_{\mathrm{jn}}-$ coefficients characterizing the weight of the k-th component in the $j$-th variable; $F_{1}, F_{2}, \ldots, F n$-the values of the main components.

Values ofajkconsidered unknown to be determined.

Models of the relationship of the initial characteristics for the open-hearth slag processing area: $\mathrm{z}_{1}=0,968 \mathrm{a}_{1}, \mathrm{z}_{2}=0,928 \mathrm{a}_{1}, \mathrm{z}_{3}=0,853 \mathrm{a}_{1}, \mathrm{z}_{4}=0,938 \mathrm{a}_{1}, \mathrm{z}_{5}=0,851 \mathrm{a}_{1}, \mathrm{z}_{6}=-0,617 \mathrm{a}_{2}, \mathrm{z}_{7}=0,804$ $\mathrm{a}_{1}, \mathrm{z}_{8}=0,725 \mathrm{a}_{1}, \mathrm{z}_{9}=0,666 \mathrm{a}_{1}+0,526 \mathrm{a}_{3}, \mathrm{z}_{10}=0,667 \mathrm{a}_{1}+0,527 \mathrm{a}_{3}, \mathrm{z}_{11}=0,665 \mathrm{a}_{1}+0,593 \mathrm{a}_{2}, \mathrm{z}_{12}=$ $0,940 a_{1}, z_{13}=-0,852 a_{2}, z_{14}=0,550 a_{4}, z_{15}=0,897 a_{2}, z_{16}=-0,694 a_{1}, z_{17}=0,634 a_{4}, z_{18}=0,722 a_{2}$.

Models of the relationship of the initial characteristics for the processing area of blast furnace slag: $\mathrm{z}_{1}=0,941 \mathrm{a}_{1}, \mathrm{z}_{2}=0,921 \mathrm{a}_{1}, \mathrm{z}_{3}=0,953 \mathrm{a}_{3}, \mathrm{z}_{4}=0,815 \mathrm{a}_{5}-0,515 \mathrm{a}_{2}, \mathrm{z}_{5}=0,932 \mathrm{a}_{1}, \mathrm{z}_{6}=0,518 \mathrm{a}_{2}, \mathrm{z}_{7}=$ $0,959 \mathrm{a}_{1}, \mathrm{z}_{8}=0,441 \mathrm{a}_{1}-0,722 \mathrm{a}_{2}, \mathrm{z}_{9}=0,896 \mathrm{a}_{1}, \mathrm{z}_{10}=0,924 \mathrm{a}_{1}, \mathrm{z}_{11}=-0,834 \mathrm{a}_{2}, \mathrm{z}_{12}=0,896 \mathrm{a}_{1}, \mathrm{z}_{13}=$ $0,722 \mathrm{a}_{2}, \mathrm{z}_{14}=0,707 \mathrm{a}_{4}, \mathrm{z}_{15}=-0,514 \mathrm{a}_{2}-0,747 \mathrm{a}_{3}, \mathrm{z}_{17}=0,818 \mathrm{a}_{3}, \mathrm{z}_{18}=-0,535 \mathrm{a}_{2}-0,720 \mathrm{a}_{3}$.

3. Meaningful interpretation of the main components. At interpretation signs in which size of loading is not less than 0,5 were considered. In tabl. 1 and 2, such features are highlighted in bold. tabl. 3 .

Comparative analysis of the load of the components on the studied features are presented in 
Table 3. Comparative analysis of the load of components on the studied features

\begin{tabular}{|c|c|c|c|c|c|c|c|c|}
\hline \multirow{3}{*}{$\begin{array}{c}\text { Output } \\
\text { parameters }\end{array}$} & \multicolumn{8}{|c|}{ Weight coefficients } \\
\hline & $\mathrm{a}_{1}$ & $\mathrm{a}_{2}$ & $\mathrm{a}_{3}$ & $\mathrm{a}_{4}$ & $a_{1}$ & $a_{2}$ & $\mathrm{a}_{3}$ & $\mathrm{a}_{4}$ \\
\hline & \multicolumn{4}{|c|}{ Open-hearth slag processing site } & \multicolumn{4}{|c|}{ Blast furnace slag processing site } \\
\hline $\mathrm{Z}_{1}$ & + & - & - & - & + & - & - & - \\
\hline $\mathrm{Z}_{2}$ & + & - & - & - & + & - & - & - \\
\hline $\mathrm{Z}_{3}$ & + & - & - & - & + & - & - & - \\
\hline $\mathrm{Z}_{4}$ & + & - & - & - & + & + & - & - \\
\hline $\mathrm{Z}_{5}$ & + & - & - & - & + & - & - & - \\
\hline $\mathrm{z}_{6}$ & - & + & - & - & - & + & - & - \\
\hline $\mathrm{Z}_{7}$ & + & - & - & - & + & - & - & - \\
\hline $\mathrm{Z}_{8}$ & + & - & - & - & - & + & - & - \\
\hline $\mathrm{Z}_{9}$ & + & - & + & - & + & - & - & - \\
\hline $\mathrm{Z}_{10}$ & + & - & + & - & + & - & - & - \\
\hline $\mathrm{Z}_{11}$ & + & + & - & - & - & + & - & - \\
\hline $\mathrm{Z}_{12}$ & + & - & - & - & + & - & - & - \\
\hline $\mathrm{Z}_{13}$ & - & + & - & - & - & + & - & - \\
\hline $\mathrm{Z}_{14}$ & - & - & - & + & - & - & - & + \\
\hline $\mathrm{Z}_{15}$ & - & + & - & - & - & + & + & - \\
\hline $\mathrm{Z}_{16}$ & + & - & - & - & - & - & - & - \\
\hline $\mathrm{Z}_{17}$ & - & - & - & + & - & - & + & - \\
\hline$Z_{18}$ & - & - & - & - & - & + & + & - \\
\hline
\end{tabular}

Note: "+" indicates the factor loads included in the model, and "-", which are not included

Let's analyze the process of dump trucks in the area of open-hearth slag processing.

The first component has significant loads on the following features: number of rides $\left(\mathrm{z}_{1}\right)$, volume of cargo transported $\left(\mathrm{z}_{2}\right)$, mileage $\left(\mathrm{z}_{3}\right)$, number of operating hours $(\mathrm{z} 4)$, actual fuel consumption $\left(\mathrm{z}_{5}\right)$, travel time $\left(\mathrm{z}_{7}\right)$, idling $\left(\mathrm{z}_{8}\right)$, duration of stops $\left(\mathrm{z}_{9}\right)$, number of stops $\left(\mathrm{z}_{10}\right)$, duration of stops $\left(\mathrm{z}_{11}\right)$, number of stops $\left(\mathrm{z}_{12}\right)$, coefficient of static capacity utilization $\left(\mathrm{z}_{14}\right)$, average driving distance $\left(\mathrm{z}_{15}\right)$.

The second component reflects the influence of five essential features: technical speed (z6), duration of stops $\left(\mathrm{z}_{11}\right)$; operating speed $\left(\mathrm{z}_{13}\right)$, average driving time $\left(\mathrm{z}_{15}\right)$, idle time under load (unloading) $\left(\mathrm{z}_{16}\right)$. $\operatorname{ing}\left(\mathrm{z}_{10}\right)$.

The third component includes the following features: duration of parking $\left(\mathrm{z}_{9}\right)$, number of park-

The fourth positive relationship with the fourth component is the coefficient of static load capacity $\left(\mathrm{z}_{14}\right)$, the average ride length $\left(\mathrm{z}_{17}\right)$.

Let's analyze the process of dump trucks at the blast furnace slag processing site.

The first component has a significant load on the following features: number of rides $\left(\mathrm{z}_{1}\right)$, volume of cargo transported $\left(\mathrm{z}_{2}\right)$, mileage $\left(\mathrm{z}_{3}\right)$, number of operating hours $\left(\mathrm{z}_{4}\right)$, actual fuel consumption $\left(\mathrm{z}_{5}\right)$, travel time $\left(\mathrm{z}_{7}\right)$, duration of parking $\left(\mathrm{z}_{9}\right)$, number of stops $\left(\mathrm{z}_{10}\right)$, number of stops $\left(\mathrm{z}_{12}\right)$.

The second component has a load on the following features: the number of operating hours $(\mathrm{z} 4)$, technical speed $\left(\mathrm{z}_{6}\right)$, idling $\left(\mathrm{z}_{8}\right)$, duration of stops $\left(\mathrm{z}_{11}\right)$; operating speed $\left(\mathrm{z}_{13}\right)$, average driving time $\left(\mathrm{z}_{15}\right)$, idle time under load (unloading) $\left(\mathrm{z}_{18}\right)$.

The third component includes the following features: average ride duration $\left(\mathrm{z}_{15}\right)$, average ride length $\left(\mathrm{z}_{17}\right)$, idle time under load (unloading) $\left(\mathrm{z}_{18}\right)$. utilization $\left(\mathrm{z}_{14}\right)$.

The fourth positive relationship with the fourth component is the coefficient of static capacity formed.

From the principal components identified in the analysis, two homogeneous groups can be

The first group includes the first and fourth main components, which are a summary of the effectiveness of dump trucks.

The second group can be described as the degree of use of dump trucks. 


\section{Conclusions}

Based on the results of research, the following conclusions can be drawn.

1. The method of the main components in combination with engineering and economic information about the physical nature of the real process is a good tool for grouping interrelated factors in accordance with their economic content.

2. The use of the principal components method makes it possible to move to the modeling of the studied process using a limited set of new variables, which simplifies the procedure of economic and statistical analysis and makes it more efficient.

3. The use of component analysis makes it possible to construct analytical expressions of generalized factors through a system of interrelated primary parameters.

4. Among the obtained set of generalized factors can be distinguished homogeneous groups that characterize certain complex characteristics of the production process.

The selected main components can be used as generalized factors to approximate the performance of the cargo processing process using a linear regression model.

\section{References}

[1] Mokeev V. V., Solomaho K. L. (2013) Ob ispol'zovanii metoda glavnyh komponent dlya analiza deyatel'nosti predpriyatij [On the use of the method of principal components to analyze the activities of enterprises] Vestnik YUzhno-Ural'skogo gosudarstvennogo universiteta. Seriya: Ekonomika i menedzhment - Bulletin of the South Ural State University. Series: Economics and Management, (№3), 41-46 [in Russian].

[2] Mokeev V. V. (2010) Reshenie problemy` sobstvenny`kh znachenij v zadachakh mnogofaktornogo analiza e'konomicheskikh sistem [Solving the problem of eigenvalues in the problems of multivariate analysis of economic systems] E'konomika i matematicheskie metody'-Economics and Mathematical Methods, (№ 4), 82-90 [in Russian].

[3] Kalinina V. N., V. I. Solov`ev. (2003) Vvedenie v mnogomerny`j statisticheskij analiz: Uchebnoe posobie [Introduction to Multivariate Statistical Analysis]. Moscow: ГУУ [in Russian].

[4] Mokeev V. V., Pluzhnikov V. G. (2011) Analiz glavny`kh komponent kak sredstvo povy`sheniya e'ffektivnosti upravlencheskikh reshenij v predprinimatel'skikh strukturakh [Analysis of the main components as a means of increasing the efficiency of management decisions in business structures] Vestnik YUzhno-Ural'skogo gosudarstvennogo universiteta Seriya: E'konomika i menedzhment - Bulletin of the South Ural State University. Series: Economics and Management, (№41), 149-154 [in Russian].

[5] Borovikov V. P., I. P. Borovikov (1998) STATISTICA - Statisticheskij analiz i obrabotka danny'kh v srede Windows [STATISTICA - Statistical analysis and data processing in the environment Windows]. Moscow: Filin [in Russian].

[6] Lashhenikh, O. A., Turpak S. M, Griczaj S. V. (2012) Dosli`dzhennya transportno-sklads koyi sistemi metodom golovnikh komponenti $\mathrm{v}$ [Research of transport and warehousing system by the method of main components] Vi'snik Dni'propetrovs'kogo naczi`onal'nogo uni'versitetu zali znichnogo transportu i'm. akad. V. Lazaryana - Bulletin of Dnepropetrovsk National University of Railway Transport. akad. V. Lazaryana. (№ 40), 208-216 [in Ukrainian].

[7] Borovikov V.P. STATISTICA - Statistical analysis and data processing in the Windows environment / VP Borovikov, I.P.Borovikov. M.: Information and Publishing House "Filin", 1998. 608 p.

[8] Dubrov A. M. (1978) Obrabotka statisticheskikh danny'kh metodom glavny'kh komponent. [Processing of statistical data by the method of the main components]. Moscow: Statistika [in Russian].

[9] Kharman G. (1972) Sovremenny’j faktorny’j analiz. [Modern factor analysis]. Moscow: Statistika [in Russian].

[10] Andrukovich P. F. (1973) Primenenie metoda glavny`kh komponent v prakticheskikh issledovaniyakh. Mezhfakul tetskaya laboratoriya statisticheskikh metodov [Application of the principal component analysis in practical research]. Moscow: MGU [in Russian]. 


\section{ДОСЛІДЖЕННЯ РОБОТИ САМОСКИДІВ В ТРАНСПОРТНО- ТЕХНОЛОГІЧНІЙ СИСТЕМІ РЕЦИКЛІНГУ ТЕХНОЛОГІЧНИХ ВІДХОДІВ МЕТАЛУРГІЙНОГО ПІДПРИЕМСТВА МЕТОДОМ ГОЛОВНИХ КОМПОНЕНТ Середа Б.П., Муковська Д.Я., Середа Д.Б.}

\section{Реферат}

В процесі даного дослідження були опрацьовані статистичні данні про роботу великовантажних самоскидів БелАЗ вантажопідйомністю 30 та 42 т в транспортно-технологічній системи рециклінгу технологічних відходів двох ділянок цеху шлакопереробки протягом 31 доби. Експертним шляхом були виділені 18 параметрів, які характеризують якісну роботу самоскидів, а саме, - кількість їздок $\left(\mathrm{z}_{1}\right)$, обсяг перевезеного вантажу $\left(\mathrm{z}_{2}\right)$, пробіг $\left(\mathrm{z}_{3}\right)$, кількість моточасів роботи $\left(\mathrm{z}_{4}\right)$, фактична витрата палива $\left(\mathrm{z}_{5}\right)$, технічна швидкість руху $\left(\mathrm{z}_{6}\right)$, час у русі $\left(\mathrm{z}_{7}\right)$, холостий хід $\left(\mathrm{z}_{8}\right)$, тривалість стоянок $\left(\mathrm{z}_{9}\right)$, кількість стоянок $\left(\mathrm{z}_{10}\right)$, тривалість зупинок $\left(\mathrm{z}_{11}\right)$, кількість зупинок $\left(\mathrm{z}_{12}\right)$, експлуатаційна швидкість руху $\left(\mathrm{z}_{13}\right)$, коефіцієнт статичного використання вантажопідйомності $\left(\mathrm{z}_{14}\right)$, середня тривалість їздки $\left(\mathrm{z}_{15}\right)$, середня відстань їздки $\left(\mathrm{z}_{16}\right)$, середня довжина їздки $\left(\mathrm{z}_{17}\right)$, час простою під завантаженням (розвантаженням) $\left(\mathrm{z}_{18}\right)$. Практична реалізація методу здійснена на ЕОМ у модулі «Факторний аналіз» інтегрованої системи статистичного аналізу STATISTICA. В процесі компонентного аналізу було обгрунтовано кількість найбільш вагових головних компонент, встановлено співвідношення між головними компонентами і вихідними параметрами, проведено змістовне інтерпретування головних компонент.

\section{Література}

1. Мокеев В. В., Соломахо К. Л. Об использовании метода главных компонент для анализа деятельности предприятий. Вестник Южно-Уральского государственного университета. Серия: Экономика и менеджмент. 2013. Т. 7. №. 3. С. 41-46.

2. Мокеев В. В. Решение проблемы собственных значений в задачах многофакторного анализа экономических систем. Экономика и математические методы. 2010. №. 4. С. 82-90.

3. Калинина В. Н., В. И. Соловьев. Введение в многомерный статистический анализ: Учебное пособие. ГУУ. М., 2003. $66 \mathrm{c.}$

4. Мокеев В. В., Плужников В. Г. Анализ главных компонент как средство повышения эффективности управленческих решений в предпринимательских структурах. Вестник ЮжноУральского государственного университета. Серия: Экономика и менеджмент. 2011. №. 41. C. $149-154$.

5. Боровиков В. П., И. П. Боровиков STATISTICA - Статистический анализ и обработка данных в среде Windows. М.: Информационно-издательский дом «Филинъ», 1998. 608 с.

6. Лащених, О. А., Турпак С. М, Грицай С. В. Дослідження транспортно-складської системи методом головних компонентів. Вісник Дніпропетровського національного університету залізничного транспорту ім. акад. В. Лазаряна. 2012. Вип. 40. С. 208-216.

7. Боровиков В. П., Боровиков И. П. STATISTICA - Статистический анализ и обработка данных в среде Windows,. М.: Информационно-издательский дом «Филинъ», 1998. 608 с.

8. Дубров А. М. Обработка статистических данных методом главных компонент. М.: Статистика, 1978. 135 с.

9. Харман Г. Современный факторный анализ. М.: Статистика, 1972. 486 с.

10. Андрукович П. Ф. Применение метода главных компонент в практических исследованиях. Межфакультетская лаборатория статистических методов. М.: МГУ, 1973, вып. 36. 124 с 